${ }^{2}$ Kavli G. Pemphigus vulgaris and thymoma. A T-lymphocyte defect. $B r \mathcal{F}$ Dermatol 1978;99:97-8.

3 Townley RG, Ford L. Possible immune origin of pemphigus. $N$ Engl $\mathcal{f}$ Med 1982;307:1213.

4 Reinherz EC, Schlossman SF. Regulation of the immune response inducer and suppressor T-lymphocyte subsets in human beings. $N$ Engl f Med $1980 ; 303: 370-3$.

B Ballow M, Park BH, Dupont B, Caldwell RR, Lonsdale D, Gold RA. Benign giant lymphoid hyperplasia of the mediastinum with associated abnormalities of the immune system. F Pediatr 1974;84:418-20.

(Accepted 24 August 1983)

Servicio de Medicina Interna, Residencia Sanitaria de Sagunto, Sagunto, Spain

J REDON, MD, chief, service of internal medicine

Ciudad Sanitaria La Fe, Valencia, Spain

G SORNI, MD, chief, section of dermatology

A GONZALEZ-MOLINA, MD, chief, section of immunology

$M$ CABALLERO, MD, chief, service of internal medicine

J BAGUENA, MD, chairman of department of medicine

\section{Accuracy of insulin injection in elderly patients}

Good control of diabetes depends on the patient being capable of consistently injecting accurate amounts of insulin. Problems with self administration of insulin might be expected in patients suffering from confusion or impaired vision or coordination. Thus older diabetic patients might be at particular risk from errors in the amounts of insulin injected. We investigated this hypothesis and the possible merits of different insulin syringes.

\section{Patients, methods, and results}

We studied nine diabetic patients with an age range of 56-81 (mean 66) years who had been treated with self administered insulin for at least one year. Patients with impaired vision, cognition, or coordination were excluded from the study. Nine doctors and nurses with normal vision who were trained in administering insulin served as controls.

We used ${ }^{125}$ I (as sodium iodide) as a label. A reference solution was established, and $500 \mu \mathrm{l}$ of it was drawn up with a semiautomatic Oxford pipette as a standard for volume measurements. By measuring the gamma particles emitted from the test samples and comparing this with the standard solution we obtained an accurate measurement of the volume of the test fluid.

Estimation of dead space-Altogether $0.5 \mathrm{ml}$ of labelled solution was withdrawn with one of four insulin syringes (Chance glass, Plastipak SFP, Sabre disposable, Plastipak polypropylene). The solution was then expelled to the zero marker and discarded. The aliquot remaining in the syringe was termed the dead space. This was extracted by four washings of the syringe with $0.5 \mathrm{ml}$ saline. The counts of ${ }^{125} \mathrm{I}$ from the collected washings were then measured to calculate the dead space. Ten measurements were made for each type of syringe. The Plastipak SFP syringe had a dead space of $0.01 \mathrm{ml}$ whereas the Chance glass, Sabre disposable, and Plastipak polypropylene syringes had dead spaces of $0.12 \mathrm{ml}, 0.13 \mathrm{ml}$, and $0.12 \mathrm{ml}$, respectively.

Accuracy of insulin dose-The patients and controls withdrew and expelled 20 units $(0.5 \mathrm{ml})$ of labelled solution with their usual syringes (Sabre disposable or Chance glass). The controls used a Sabre disposable with a 23 gauge needle. This was repeated three times. The three expelled samples were counted for ${ }^{125}$ I activity and the actual volumes expelled were calculated. The table shows the individual results in patients and controls. The mean variation in dose was $4.4 \%$ in the controls compared with $12 \cdot 2 \%$ in the patients.

\section{Comment}

Our results show a considerable dead space in three commonly used types of insulin syringes. This means a wastage of $12 \%$ if $1.0 \mathrm{ml}$ insulin is required and $24 \%$ if only $0.5 \mathrm{ml}$ insulin is required. If a patient is taking a mixture of insulins in one syringe the dead space may alter the relative proportions of insulins actually being injected. This would be particularly important in patients with altering insulin requirements or when different types of syringe are used. Unless care is taken unplanned proportions of the insulins will
Accuracy of amount of insulin administered on three occasions by each patient and control

\begin{tabular}{|c|c|c|c|c|c|}
\hline \multirow{2}{*}{$\begin{array}{c}\text { Age } \\
\text { (years) }\end{array}$} & \multirow{2}{*}{$\begin{array}{c}\text { Insulin syringe } \\
\text { used }\end{array}$} & \multicolumn{3}{|c|}{ Individual $\%$ error } & \multirow{2}{*}{ Mean $\%$ error } \\
\hline & & First & Second & Third & \\
\hline $\begin{array}{l}28 \\
27 \\
23 \\
25 \\
32 \\
26 \\
25 \\
24 \\
37\end{array}$ & $\begin{array}{l}\text { Sabre disposable } \\
\text { Sabre disposable } \\
\text { Sabre disposable } \\
\text { Sabre disposable } \\
\text { Sabre disposable } \\
\text { Sabre disposable } \\
\text { Sabre disposable } \\
\text { Sabre disposable } \\
\text { Sabre disposable }\end{array}$ & $\begin{array}{l}\quad C \\
+3.0 \\
+2 \cdot 4 \\
-1.8 \\
+5 \cdot 6 \\
-3 \cdot 6 \\
+6.8 \\
-5.2 \\
+8.2 \\
+3.4\end{array}$ & $\begin{array}{r}\text { trols } \\
+3.9 \\
+5.4 \\
+4.5 \\
+2.4 \\
+6.9 \\
-1.6 \\
-3.2 \\
-2.4 \\
-4.1\end{array}$ & $\begin{array}{l}+3 \cdot 4 \\
+4 \cdot 8 \\
+5 \cdot 1 \\
+6 \cdot 4 \\
+5 \cdot 1 \\
+3 \cdot 3 \\
+6 \cdot 8 \\
-2 \cdot 3 \\
+7 \cdot 5\end{array}$ & $\begin{array}{l}3 \cdot 5 \\
4 \cdot 2 \\
3 \cdot 8 \\
4 \cdot 8 \\
5 \cdot 2 \\
3 \cdot 9 \\
5 \cdot 1 \\
4 \cdot 3 \\
5 \cdot 0\end{array}$ \\
\hline $\begin{array}{l}56 \\
59 \\
62 \\
61 \\
68 \\
70 \\
81 \\
72 \\
70\end{array}$ & $\begin{array}{l}\text { Sabre disposable } \\
\text { Sabre disposable } \\
\text { Chance glass } \\
\text { Sabre disposable } \\
\text { Chance glass } \\
\text { Sabre disposable } \\
\text { Sabre disposable } \\
\text { Sabre disposable } \\
\text { Sabre disposable }\end{array}$ & $\begin{aligned} & P \\
&+ 5 \cdot 9 \\
&+9 \cdot 2 \\
&+12 \cdot 1 \\
&+19 \cdot 2 \\
&+11 \cdot 1 \\
&+19 \cdot 1 \\
&-7 \cdot 2 \\
&+16 \cdot 3 \\
&+13 \cdot 5\end{aligned}$ & $\begin{array}{l}\text { ients } \\
+6 \cdot 0 \\
+7.8 \\
+8.0 \\
+17 \cdot 0 \\
+8.4 \\
-11 \cdot 1 \\
-4.9 \\
+9.7 \\
+18.2\end{array}$ & $\begin{array}{r}-7.4 \\
-8.6 \\
-11 \cdot 1 \\
+24.8 \\
+13.2 \\
-17.9 \\
+9.1 \\
+12.1 \\
+19.1\end{array}$ & $\begin{array}{r}6 \cdot 4 \\
8 \cdot 5 \\
10 \cdot 4 \\
20 \cdot 3 \\
10 \cdot 9 \\
16 \cdot 1 \\
7 \cdot 1 \\
12 \cdot 7 \\
16 \cdot 9\end{array}$ \\
\hline
\end{tabular}

be given, resulting in disturbed control of diabetes and particularly the risk of hypoglycaemia. It may be desirable in these circumstances to use a "premixed" insulin such as Initard (Nordisk) or Mixtard (Nordisk) or a similar mixture prepared in the hospital pharmacy.

Kesson and Bailie showed a $19 \%$ error in insulin dose in older diabetic patients. ${ }^{1}$ Our study showed a smaller inaccuracy (mean of $12 \cdot 2 \%$ ) Dossibly because visual and neurological disorders were specifically used as exclusion criteria. All our patients had been self administering their insulin for at least one year. This inaccuracy in the insulin dose administered may contribute to management problems in elderly diabetics. In such patients more use should be made of preset insulin syringes of the type used for the partially sighted.

${ }^{1}$ Kesson CM, Bailie GR. Do diabetic patients inject accurate doses of insulin. Diabetes Care. $1981 ; 4: 333$.

(Accepted 24 August 1983)

Hope Hospital, Salford M6 8HD

J A H PUXTY, MB, MRCP, lecturer in geriatric medicine

Leeds General Infirmary, Leeds

D H HUNTER, MB, MRCP, registrar in medicine

Pindersfield General Hospital, Wakefield

W A BURR, MD, MRCP, consultant physician

Correspondence to: Dr J A H Puxty.

\section{Treatment of hypercalcaemia in sarcoidosis with flurbiprofen}

A previously fit man presented with sarcoidosis complicated by hypercalcaemia. He was treated with flurbiprofen, a potent prostaglandin synthetase inhibitor, and his serum calcium concentration rapidly fell within the normal range. Further investigations suggested that this fall was due to inhibition of bone resorption induced by prostaglandin.

\section{Case report}

A previously fit 29 year old solicitor, who was also a first class rugby player, presented with a history of epigastric discomfort, thirst and polyuria, slight weight loss, and general malaise. There were no abnormal physical findings, and a chest $x$ ray film showed bilateral hilar lymphadenopathy with enlarged paratracheal lymph nodes. Sarcoidosis was provisionally diagnosed, and he was admitted to hospital. Investigations supporting this diagnosis included a positive reaction to a Kveim test, serum angiotensin converting enzyme activity of 63 IU/1 (normal range 20-55 IU/1), $\beta_{2}$ microglobulin concentration of $3.55 \mathrm{mg} / 1$ (normal range $1.2-2.4 \mathrm{mg} / 1$ ), and a negative reaction to a Mantoux test at a $1: 100$ dilution.

Serum calcium concentration (normal range $2 \cdot 25-2 \cdot 60 \mathrm{mmol} / 1$ (9.0$10.4 \mathrm{mg} / 100 \mathrm{ml})$ ) was $2 \cdot 89,3.09$, and $2.93 \mathrm{mmol} / 1(11 \cdot 6,12 \cdot 4$, and $11.7 \mathrm{mg} /$ $100 \mathrm{ml}$ ) on three consecutive days, and serum albumin concentration was 40,45 , and $43 \mathrm{~g} / 1$ respectively (normal range 35-48 g/1). Parathyroid hormone 
concentration was $0.62 \mu \mathrm{g} / \mathrm{l}$ on one occasion and undetectable $(<0.2 \mu \mathrm{g} / \mathrm{l})$ on another (normal concentration $<1 \mu \mathrm{g} / \mathrm{l}$ ). Serum inorganic phosphate concentration and alkaline phosphatase activity were within normal ranges. Flurbiprofen $50 \mathrm{mg}$ three times a day was given, and after seven days of treatment the serum calcium concentration had fallen to $2.55 \mathrm{mmol} / \mathrm{l}$ $(10.2 \mathrm{mg} / 100 \mathrm{ml})$ and after 21 days was $2.33 \mathrm{mmol} / 1(9.3 \mathrm{mg} / 100 \mathrm{ml})$. Treatment with flurbiprofen was continued for a further four weeks, and serum calcium concentration remained within the normal range during this period and for a further six months after treatment was stopped. His symptoms had resolved within 48 hours of the start of treatment.

Six months after flurbiprofen was stopped symptoms recurred, and the serum calcium concentration was again found to be raised $(2.76 \mathrm{mmol} / 1$ $(11.1 \mathrm{mg} / 100 \mathrm{ml})$ ) with a serum albumin concentration of $42 \mathrm{~g} / \mathrm{l}$. On this occasion he was admitted to hospital for more extensive study. He consumed a normal ward diet containing a daily intake of at least $800 \mathrm{mg}$ calcium. After an overnight fast blood and two hour fasting urine samples were collected, and biochemical and hormonal variables were measured by methods previously reported. ${ }^{1}$

After initial study treatment with flurbiprofen in the same dose as during the first hypercalcaemic episode was started, and fasting blood and urine samples were taken after 10 days. The two sets of results are shown in the table.

Biochemical variables before and after successful treatment of hypercalcaemia with flurbiprofen $50 \mathrm{mg}$ three times a day

\begin{tabular}{|c|c|c|c|}
\hline & $\begin{array}{l}\text { Before } \\
\text { treatment }\end{array}$ & $\begin{array}{c}\text { After } \\
\text { treatment }\end{array}$ & $\begin{array}{c}\text { Normal } \\
\text { range }\end{array}$ \\
\hline $\begin{array}{l}\text { Serum calcium (mmol/l) } \\
\text { Serum phosphate }(\mathrm{mmol} / \mathrm{l}) \\
\text { Serum creatinine ( }(\mu \mathrm{mol} / \mathrm{l}) \\
\text { Serum alkaline phosphatase (IU/1) } \\
\text { Serum parathyroid hormone }(\mu \mathrm{g} / \mathrm{l}) \\
\text { Serum } 1,25-\text { dihydroxy vitamin } \mathrm{D} \text { (pmol/1) } \\
\text { Urine calcium ( } \mu \text { mol/1 glomerular filtrate) } \\
\text { Urine phosphate }(\mu \mathrm{mol} / 1 \text { glomerular filtrate) } \\
\text { Urine calcium:creatinine } \\
\text { Urine hydroxyproline:creatinine }\end{array}$ & $\begin{array}{l}2 \cdot 81 \\
1 \cdot 11 \\
140 \\
83 \\
0 \cdot 70 \\
16 \cdot 0 \\
198 \cdot 8 \\
405 \cdot 5 \\
1.42 \\
0.033\end{array}$ & $\begin{array}{c}2 \cdot 38 \\
1 \cdot 29 \\
130 \\
104 \\
0 \cdot 66 \\
17 \cdot 4 \\
109 \cdot 5 \\
306 \cdot 4 \\
0 \cdot 84 \\
0.006\end{array}$ & $\begin{array}{l}2 \cdot 26-2 \cdot 60 \\
0 \cdot 80-1 \cdot 45 \\
60-120 \\
30-95 \\
<1 \\
5-15 \\
<40 \\
<218 \\
<0.425 \\
<0.022\end{array}$ \\
\hline $\begin{array}{l}\text { Tubular reabsorption of calcium (mmol/l } \\
\text { glomerular filtrate) }\end{array}$ & 1.64 & 1.52 & $1 \cdot 80-2 \cdot 20$ \\
\hline $\begin{array}{l}\text { Tubular reabsorption of phosphate } \\
\text { (mmol/1 glomerular filtrate) }\end{array}$ & 0.78 & $1 \cdot 14$ & $0 \cdot 7-1 \cdot 4$ \\
\hline
\end{tabular}

Conversion: $S I$ to traditional units-Serum calcium: $1 \mathrm{mmol} / 1 \approx 4 \mathrm{mg} / 100 \mathrm{ml}$. Serum phosphate: $1 \mathrm{mmol} / 1 \approx 3.1 \mathrm{mg} / 100 \mathrm{ml}$. Serum creatinine: $1 \mathrm{mmol} / 1 \approx 11.3 \mathrm{mg} /$ $100 \mathrm{ml}$. 1,25-dihydroxy vitamin $\mathrm{D}: 1 \mathrm{pmol} / 1 \approx 4 \mathrm{pg} / \mathrm{ml}$. Urine calcium: $1 \mu \mathrm{mol} / 1$ glomerular filtrate $\approx 40 \mathrm{ng} / \mathrm{ml}$. Urine phosphate: $1 \mu \mathrm{mol} / 1$ glomerular filtrate $\approx 31 \mathrm{ng} /$ Tubular reabsorption of phosphate: $1 \mathrm{mmol} / 1$ glomerular filtrate $\approx 3.1 \mathrm{mg} / 100 \mathrm{ml}$.

\section{Comment}

The data indicated that the hypercalcaemia was mainly resorptive in origin and that, after treatment with flurbiprofen, serum calcium concentration fell to within the normal range largely because of a reduction in bone resorption. Raised serum concentrations of 1,25dihydroxy vitamin $\mathrm{D}$ are generally associated with increased absorption of calcium from the gastrointestinal tract, ${ }^{2}$ and 1,25 -dihydroxy vitamin $\mathrm{D}$ is also a potent bone resorbing agent. Raised concentrations of 1,25-dihydroxy vitamin $\mathrm{D}$ have been reported in patients with sarcoidosis and hypercalcaemia, and it has been suggested that corticosteroids relieve hypercalcaemia by lowering these concentrations and hence reducing calcium absorption. ${ }^{3}$ Steroids may also directly reduce synthesis of prostaglandin. ${ }^{4}$

Plasma concentrations of 1,25-dihydroxy vitamin $\mathrm{D}$ in our patient were raised before and after treatment, and we therefore do not believe that increased production of 1,25-dihydroxy vitamin $\mathrm{D}$ was causing increased bone resorption. Prostaglandins, particularly of the $\mathbf{E}$ series, are potent bone resorbing agents and have been thought to be responsible for hypercalcaemia associated with some soft tissue malignancies. ${ }^{5}$ Although we were unable to measure production of prostaglandin directly, our data are best explained by increased absorption of bone induced by prostaglandin and occurring independently of changes in calcium absorption. The latter were caused by raised concentrations of 1,25-dihydroxy vitamin D and were rapidly corrected by flurbiprofen.

Prostaglandin synthetase inhibitors may be useful in patients with sarcoidosis and hypercalcaemia, particularly when the catabolic effects of corticosteroids are to be avoided.

${ }^{1}$ Nordin BEC. Diagnostic procedures. In: Calcium, phosphate and magnesium metabolism. London: Edinburgh, and New York: Churchill Livingstone, 1976.

${ }^{2}$ Haussler MR, McCain JP. Basic and clinical concepts related to vitamin D metabolism and action. N Engl f Med 1977;297:974-83, 1041-50.

${ }^{3}$ Papapoulos SE, Clement TL, Fraher LJ, Lewin IG, Sandler LM, O'Riordan JL. 1,25-dihydroxycholecalciferol in the pathogenesis of the hypercalcaemia of sarcoidosis. Lancet $1969 ; \mathrm{i}: 627-30$.

4 Ibbotson KJ, D'Souza SM, Kanis JA, Douglas DL, Russell RGG.
Physiological and pharmacological regulation of bone resorption. Metab Bone Dis Relat Res 1980;2:177-89.

5eyberthe HW, Segre GV, Morgan JL, Sweetman BJ, Potts JT, Oates JA. Prostaglandins as mediators of hypercalcaemia associated with certain types of cancer. $N$ Engl F Med 1975;293:1278-83.

(Accepted 18 August 1983)

Department of Medicine, Llandough Hospital, Penarth, South Glamorgan

T LITTI_EWOOD, MB, MRCP, registrar

A HUNTER, MB, MRCP, senior registrar

PETER BECK, MB, FRCP, consultant

Department of Medicine, University Hospital of Wales, Cardiff CF4 4XN

P J HEYBURN, MB, MRCP, senior registrar

Department of Medical Biochemistry, Welsh National School of Medicine, Cardif CF4 4XN

R C BROWN, PHD, research fellow

Correspondence to: Dr T Littlewood.

\section{Testicular pain caused by mazindol}

Testicular pain is an unusual adverse effect of a drug. We provide details of eight voluntary reports sent to the Australian and Netherlands national centres for monitoring drug safety attributing this symptom to the anorectic drug mazindol. This drug is marketed in Australia as Sanorex and in the Netherlands as Teronac.

\section{Case reports}

\section{AUSTRALIA}

Case 1 -In 1975 a 37 year old diabetic man weighing $93.7 \mathrm{~kg}$ took mazindol $1 \mathrm{mg}$ daily. Within 48 hours he developed pain in the testes, which retracted and became round and hard. He also experienced dysuria with a poor erratic stream. He recovered when he stopped taking the drug. He took mazindol again on four occasions and each time the symptoms recurred within 24 hours.

Case 2-In 1976 a 57 year old man weighing about $95 \mathrm{~kg}$ was taking alprenolol hydrochloride for angina and prochlorperazine maleate for Menière's syndrome. His prostate was moderately enlarged. He then also took mazindo $1 \mathrm{mg}$ daily and after about one month developed painful testes, which were sore to touch, and dysuria. The symptoms resolved within 24 hours of stopping the drug and recurred within 12 hours on each of three occasions when he took it again.

Case 3-In 1978 a healthy 38 year old man weighing about $73 \mathrm{~kg}$ took one mazindol tablet daily for more than a month. Four hours after taking the firs tablet he experienced testicular pain. He complained of minor swelling in his testes when voiding and of a seminal discharge each time he had a bowel action. The problem was treated as prostatitis but resolved completely when mazindol was stopped. Rechallenge led to recurrence. Details of this patien have been published.

Case 4-In 1982 a 34 year old man weighing $96 \mathrm{~kg}$ and not taking other drugs took mazindol $2 \mathrm{mg}$ daily. After taking the first tablet he experienced very severe pain in his testes and groin. Symptoms began about two hours after taking the drug and resolved within eight hours. They recurred when he took it on each of the next two days. About 14 days later he again took the drug with the same result. He also complained of "penile shrinkage" and possibly had erectile impotence each time he took mazindol.

Case 5-In 1983 a 29 year old man weighing $115 \mathrm{~kg}$ was taking allopurinol for hyperuricaemia. He then also took mazindol $0.5 \mathrm{mg}$ daily for one week and then $1.0 \mathrm{mg}$ daily for about two months. After about eight weeks of treatmen with mazindol he developed impotence, sore testes, and non-orgasmic spontaneous ejaculation that resolved promptly when he stopped taking the drug. He had no history of sexual dysfunction.

\section{NETHERLANDS}

Case 6-In 1977 a 36 year old man was reported to have developed a "prostatitis like" condition with painful micturition, painful testes, and lower abdominal pain after taking mazindol for obesity. Details of dosage were not provided. The condition occurred on each of three occasions when he took the drug. Investigation of his urine showed no sediment, and culture gave a negative result.

Case 7-In 1977 a 40 year old man took mazindol $1 \mathrm{mg}$ twice daily for about 10 days. About one hour after taking each dose he developed tender testes, which remained so on each occasion for about two hours. 